\title{
Thermal groundwaters of the UK: geochemical indications of flow, vulnerability and possible threat to the shallow hydrosphere
}

\author{
W George Darling, British Geological Survey, Wallingford \\ British Geological Survey, Maclean Building, Wallingford OX10 8BB, UK \\ (e-mail: wgd@bgs.ac.uk)
}

\begin{abstract}
Three types of thermal groundwater are known from the UK: warm springs $\left(\leq 45^{\circ} \mathrm{C}\right)$, mine inflows $\left(\leq 50^{\circ} \mathrm{C}\right)$ and deep basin waters $\left(\leq 80^{\circ} \mathrm{C}\right)$. The warm springs depend on Carboniferous Limestone conveying water to sufficient depth $(600-3000 \mathrm{~m})$ to acquire a significantly higher temperature. The springs have residence times of a few kyr, but also contain $\leq 5 \%$ modern groundwater. Their water quality is little threat to the environment; the main danger to the springs is construction activity near the emergences. Mine inflows significantly $>20^{\circ} \mathrm{C}$ are only known from Cornish granite. High dissolved ${ }^{4} \mathrm{He}$ has been interpreted as indicating long residence of the thermal component, but there is also modern water in the system, leading to uncertainty in the mean age. Unpredictable fracturing could hinder development of this resource, while the seawater-like salinity combined with the presence of toxic metals would require treatment or re-injection of the spent water to protect the near-surface environment. Mesozoic sedimentary basin brines reach temperatures $>60^{\circ} \mathrm{C}$, suitable for district heating. This resource is large and effectively invulnerable. However, these waters are generally more saline than seawater and, while disposal of spent brine could take place into the sea under favourable conditions, re-injection would be necessary for inland sites.
\end{abstract}

\section{$1 \quad$ Introduction}

For the purposes of this paper, thermal groundwaters are defined as those with a temperature of $20^{\circ} \mathrm{C}$ or greater, i.e. sufficiently above the UK mean annual air temperature of $\sim 10^{\circ} \mathrm{C}$ that seasonal effects can be ruled out, and also above the temperature of most groundwater in aquifers down to depths of a few hundred metres below surface.

In the absence of any magmatic activity in the UK for at least $55 \mathrm{Myr}$, all its thermal groundwater is a product of the background geothermal gradient pertaining in any particular area. The typical gradient in the UK is $26^{\circ} \mathrm{C} / \mathrm{km}$, but can exceed $35^{\circ} \mathrm{C} / \mathrm{km}$ mainly due to locally high amounts of radioelement decay, for example in the granite batholith of SW England (Busby 2014).

Three main types of thermal groundwater are known from the UK: warm springs, mine inflows and deep basin waters. Warm springs have of course been recognised since antiquity, the most famous instance being the use of the Bath springs by the Romans. Warm mine inflows were discovered during the course of tin mining in the Carnmenellis Granite of Cornwall in the $19^{\text {th }}$ Century. The deep basin waters are the only category to have been deliberately sought for geothermal energy, on the basis that hot groundwater must exist at depth simply because of the geothermal gradient; the technology to test this has only been readily available since the late $20^{\text {th }}$ Century. 
There may be minor exceptions to the above three categories, for example shallow groundwater could be affected locally by reinjection of cooling water at up to $50^{\circ} \mathrm{C}$ (e.g. Birks et al., 2015), and the deeper groundwater abstractions can produce water at $\mathrm{T} \geq 20^{\circ} \mathrm{C}$, e.g. the Lower Greensand aquifer in the Aldershot and Portsdown areas, but such atypical situations will not be further considered here. Instead, this paper reviews the pertinent hydrogeochemical data available from the above three categories and considers how they may inform about risks to both the shallow hydrosphere, and to the thermal resources themselves. This mainly amounts to the contamination of ground or surface water by exploitation of the resource on the one hand, and degradation of the resource - basically from dilution by cooler water - on the other.

\section{Thermal water geochemistry}

The amount of geochemical investigation of thermal groundwaters is directly proportional to their accessibility. Thus, warm springs have been extensively studied, with most effort being devoted to the higher temperature examples, principally Bath and Buxton. Mine inflows are currently inaccessible so rely on legacy data, though developments in the economics of Cornish tin mining may change that situation in the future, as may the current interest in exploiting geothermal energy in SW England. Deep basin waters are rarely accessible owing to the high cost of drilling, so also rely largely on legacy data, though these may be more comprehensive than those from the mine inflows. Each category is now considered; locations of sites and areas mentioned below are shown on the map in Fig. 1.

Most geochemical information about thermal groundwaters has traditionally been derived from inorganic hydrochemistry and the stable isotopes of $\mathrm{O}, \mathrm{H}, \mathrm{C}$ and $\mathrm{Sr}$ (e.g. Arnorsson 2000). However, information about water residence time is increasingly recognised as being of importance if the resources are to be better understood. Figure 2 shows the age ranges of indicators that have been applied in the geothermal investigations referred to below.

\subsection{Warm springs}

In the UK, these are associated exclusively with the Carboniferous Limestone of England and Wales (there are no known thermal springs in Scotland or Northern Ireland). This is a massive, fractured and often karstified limestone of Tournaisian-Viséan age which occurs in several basins across the UK. The conditions for thermal spring development include an adequate depth of circulation (600-3000 m), and a sufficiently permeable and connected fracture network to convey a small proportion of the deep warm water to the surface relatively quickly. The few warm springs presently known suggest that these conditions are rarely met. The three main occurrences are Taffs Well in South Wales (maximum $\mathrm{T} \sim 22^{\circ} \mathrm{C}$ ), the Peak District springs of central England (maximum $\mathrm{T} \sim 27^{\circ} \mathrm{C}$ ), and the springs of the Bath-Bristol Basin in southern England (maximum $\mathrm{T} \sim 45^{\circ} \mathrm{C}$ ). Unsurprisingly, the amount of geochemical attention the various spring waters have received is in direct proportion to their temperatures and hence their social and economic value. 
2.1.1 Taffs Well, SE Wales. This spring is situated on the southern side of the South Wales Coal Basin (Squirrel and Downing 1969). The water first received advanced hydrogeochemical attention during the British Geological Survey's investigation of the geothermal resources of the UK (which is summarised in Downing and Gray 1986). Burgess et al. (1980) reported a wide range of chemical, isotopic and noble-gas data, from which they concluded that recharge to the spring was derived from the north crop of the basin, which has an elevation some $500 \mathrm{~m}$ higher, and descended to a maximum depth below surface of $600 \mathrm{~m}$. A high dissolved ${ }^{4} \mathrm{He}$ concentration suggested an input of 'old' water from the underlying Old Red Sandstone (Devonian). However, the main focus of this phase of the resources investigation was on the Bath-Bristol Basin on the other side of the Bristol Channel, so the Taffs Well results received comparatively little attention. This was remedied by Farr and Bottrell (2013), who added new residence time indicator $\left({ }^{14} \mathrm{C}, \mathrm{CFCs}\right.$ and $\left.\mathrm{SF}_{6}\right)$ and $\mathrm{Sr}$ isotope results. The new data were consistent with the earlier concept of recharge on the north crop, and gave a Holocene ( $<12 \mathrm{kyr}$ ) mean residence time for the water (Table 1). However, a small proportion $(\sim 5 \%)$ of modern water was also noted, presumably reflecting a late-stage addition of cold groundwater close to the point of emergence. Strontium isotope ratios suggested that, while the Carboniferous Limestone is undoubtedly the main conduit for the thermal water, interactions with Namurian-age sandstones have contributed to the hydrochemistry of the spring.

2.1.2 The Peak District, central England. The principal warm springs of the Peak District (geologically the 'Derbyshire Dome') are those of Matlock Bath $\left(\mathrm{T} \sim 20^{\circ} \mathrm{C}\right)$ and Buxton ( $\mathrm{T} \sim 27^{\circ} \mathrm{C}$ ), with most geochemical attention being focused on the latter. Measurements of ${ }^{14} \mathrm{C}$ and ${ }^{3} \mathrm{H}$ in the 1970s on Buxton (Evans et al. 1979), since replicated (see Brassington, 2007), revealed a water with a likely bulk age of a few thousand years, but containing a small percentage of modern water (Table 1). Clearly the thermal component had time to circulate to the necessary depth of $\sim 1000 \mathrm{~m}$; unlike Taffs Well there is no regional synclinal structure nearby, though locally the Goyt Syncline is thought to reach sufficient depth (Gunn et al 2006). However, various broad anticlines and synclines are superimposed on the Derbyshire Dome (Brassington 2007), and the flowpath followed by the thermal water remains somewhat uncertain. Strontium isotope evidence suggests that sandstone units of assumed Namurian age are involved at some stage in the circulation (Gunn et al. 2006). This study also showed that the thermal water reaching Matlock Bath, as yet undated by ${ }^{14} \mathrm{C}$, is of a different origin to Buxton, with no Sr isotopic evidence for interaction with Namurian sandstones or other silicate/siliciclastic lithologies.

2.1.3 Bath-Bristol Basin. In the Bath-Bristol Basin (BBB), the known thermal springs are the small group in the centre of Bath (maximum $\mathrm{T} \sim 45^{\circ} \mathrm{C}$ ) and at Hotwells in the Avon Gorge in Bristol $\left(\mathrm{T} \sim 24^{\circ} \mathrm{C}\right.$ ). While the Bath springs issue from Mesozoic (Trias and Lias) cover, investigation boreholes indicate that Carboniferous Limestone is the ultimate source (Kellaway 1994). (Though the Bath thermal water has a notably high sulphate content, the high $\mathrm{SO}_{4}$ concentrations typically found in Liassic groundwater are not thought to contribute significantly to this as similar $\mathrm{Na} / \mathrm{SO}_{4}$ ratios are found in the Hotwells thermal spring - see below - which issues directly from Carboniferous Limestone.) The Bath thermal waters, specifically from the Stall Street borehole and the Cross Bath Spring, have been investigated using some of the most sophisticated geochemical techniques available (Table 1). The age of 
the water had been very uncertain due to the probable high dilution of active ${ }^{14} \mathrm{C}$ present in dissolved inorganic carbon (DIC) by dissolution of rock carbonate aided by the thermal water. Thus ${ }^{14} \mathrm{C}$ tends to give old apparent ages, in the case of Bath up to $14 \mathrm{kyr}$ (Burgess et al. 1980). This was felt to be unlikely since un-depleted stable isotope ratios suggested Holocene rather than Pleistocene recharge. At the other end of the timescale, Barker et al. (2000) had considered the possibility of a local circulation cell with a water residence time of only hundreds of years. In an attempt to resolve this, Edmunds et al. (2014) analysed for

${ }^{39} \mathrm{Ar}$, a noble gas with a half-life of $0.27 \mathrm{kyr}$ and therefore good for the last $\sim 1.5 \mathrm{kyr}$, after which activities become too low for precise measurement. However when measured, ${ }^{39} \mathrm{Ar}$ was found to be below detection. Combining this with the stable isotope data, the age range was reduced to 1.5-12 kyr, therefore comparable to Taffs Well and Buxton allowing for the various uncertainties. It was inferred by Edmunds et al. (2014) that for a water of perhaps $5 \mathrm{kyr}$ in age and a likely limestone porosity of $\sim 1 \%$, storage must involve the whole of the BBB rather than a narrow segment based on the 'Mendip model' (Andrews et al. 1982). Edmunds et al. (2014) also concluded that the thermal water descended to a depth of $3000 \mathrm{~m}$ in the $\mathrm{BBB}$, then lost about $20^{\circ} \mathrm{C}$ during its rise to the surface. They also confirmed by measurement of $\mathrm{CFCs}, \mathrm{SF}_{6}$ and ${ }^{85} \mathrm{Kr}$ that a few percent of cold water was entering the system close to the outlet point.

The optimistically-named Hotwells spring at present discharges onto mudflats in the tidal stretch of the River Avon, rendering sampling access very difficult. No significant geochemical measurements appear to have been made since the BBB study of Burgess et al. (1980). It has generally been assumed on geochemical grounds that the Hotwells discharge consists of Bath-type thermal water diluted approximately two-thirds by cold shallow groundwater (Smith and Darling 2012). This would be consistent with the temperature difference between the springs. A few other warm waters have been encountered in the Avon Gorge area in the past in the form of springs, wells and boreholes (Kellaway 1994), but judging from early radon measurements (Richardson 1930) the Hotwells spring is likely to contain the least-diluted thermal component.

\subsection{Mine inflows}

While flooded abandoned coal mines across the UK are being investigated as a clean energy source, their waters rarely exceed $16-20^{\circ} \mathrm{C}$ so they are not included in this study. However, during tin mining operations in and adjacent to the Carnmenellis Granite of Cornwall, SW England, hot springs or gushers were exposed by various excavations. Given that coal mines and tin mines reached similar depths, the temperature difference can mainly be ascribed to the higher geothermal gradient in the Cornubian Batholith, which is caused by elevated radioelement concentrations (Downing and Gray 1986).

Inflows in the deep mines of South Crofty-Pendarves (granite) and Wheal Jane-Mount Wellington (metapelitic aureole or 'killas') were sampled during the British Geological Survey's investigation of the geothermal resources of the UK. Edmunds et al. (1984) found a highest inflow temperature of $43^{\circ} \mathrm{C}$, compared to the $53^{\circ} \mathrm{C}$ maximum recorded in the $19^{\text {th }}$ Century (though the reliability of that figure remains unknown). Stable isotopic evidence revealed that the thermal waters, while highly saline, were the product of meteoric recharge 
rather than being seawater-derived. Radiocarbon, tritium and ${ }^{4} \mathrm{He}$ were measured in an attempt to characterise residence time. Table 2 summarises these data, which proved difficult to interpret and reconcile. On the one hand, the presence of detectable ${ }^{3} \mathrm{H}$ indicated at least some modern cold water was entering the system, while on the other hand, high concentrations of ${ }^{4} \mathrm{He}$ suggested a deep thermal component with an age in the range 100 $1000 \mathrm{kyr}$. Since the thermal component must predominate in the mix, the measured ${ }^{14} \mathrm{C}$ activities were higher than would be expected. Edmunds et al. (1984) invoked the addition of aerial thermonuclear testing-related ${ }^{14} \mathrm{C}$ to explain this, but since no contemporaneous ${ }^{14} \mathrm{C}$ measurements were made on local shallow groundwater, this remains conjecture. Given all the uncertainties of ${ }^{4} \mathrm{He}$ as a residence time indicator, it seems possible that the age and therefore storage of the thermal water is much lower than previously considered; indeed, noble-gas temperatures were consistent with Holocene rather than ice-age recharge.

The geothermal potential of one other granite has been tested by deep drilling in the UK. The concealed Weardale Granite of NE England was penetrated by a 1000-m deep borehole at Eastgate which found a maximum temperature of $46^{\circ} \mathrm{C}$ and a high reservoir transmissivity (Manning et al. 2007). The water was a brine, implying a long residence, but no specific information on the age of the water appears to have been collected.

\subsection{Deep basin waters}

By far the largest thermal water resource in the UK, potentially suitable for district heating, resides in post-Carboniferous deep sedimentary basins containing Permo-Triassic sandstones at depths $>1500 \mathrm{~m}$ and with temperatures $60-80^{\circ} \mathrm{C}$. These are restricted to England and Northern Ireland (Fig. 1), and were the target of extensive investigations during the British Geological Survey's investigation of the geothermal resources of the UK (Busby 2014). With the exception of the Cheshire Basin, each of the basins was investigated by at least one deep (1000-2000 m) cored borehole. All the basins contained saline water at depth, but ranging in concentration from less than the seawater equivalent at Kempsey in the Worcester Basin to six times at Larne in Northern Ireland (Table 3). On the basis of stable isotopes, most of the waters appear to have an overtly meteoric origin, though water in the Wessex Basin from the Marchwood, Western Esplanade and various oil exploration boreholes showed an evolutionary trend away from the meteoric line (Fig. 3 - which also shows that the amount of 'oxygen shift' is not obviously related to temperature). The main difference in basin history was that the Wessex Basin alone would have been subject to the outer ripples of Alpine folding during the Tertiary (Edmunds 1986), though why that might have affected isotope ratios remains unclear. However, there were many more deep well samples from the Wessex Basin than from the others, so it might simply be a statistical issue.

While these deep basin waters are believed not to be completely static (see Downing et al. 1987), movement must be so slow that residence times $>1$ Myr are inferred. The only attempt so far to determine age was made on water from the Marchwood well in the Wessex Basin, using the helium accumulation technique based on $U$ and Th concentrations measured in the rock core and analyses of ${ }^{4} \mathrm{He}$ in the water. Using various models for helium loss from the minerals, a median value of 15 Myr was obtained (Edmunds 1986). Though thermal 
water can still be sampled from the nearby Western Esplanade well, no other water residencetime indicators are currently available with a sufficient age range to check this.

One non-Mesozoic deep geothermal exploration borehole was drilled into the Fell Sandstone (Lower Carboniferous) beneath Newcastle under the direction of researchers from Newcastle University. A total depth of $1821 \mathrm{~m}$ was reached, with a maximum total dissolved solids (TDS) value of $225 \mathrm{~g} / \mathrm{L}$ being measured. While a bottom-hole temperature of $73^{\circ} \mathrm{C}$ was measured, transmissivity was very low compared with the Fell Sandstone near outcrop (Younger et al. 2016). The water had a much higher proportion of $\mathrm{Ca}$ than the PermoTriassic brines, but was similar in character to deep coal mine waters elsewhere in NE England (Younger et al. 2015). As with the Weardale Granite borehole (see above), no specific data relatable to water residence time has been reported.

\section{Contamination risk to shallow groundwater resources}

The cooler thermal springs such as Taffs Well and Buxton are of generally good quality; indeed some $200 \times 10^{6}$ litres per year of Buxton water are currently bottled as a mineral water, a legally-defined category requiring that there be no chemical treatment of the water. Clearly, if leakage of such waters into local river or shallow groundwater bodies were to occur, through natural or anthropogenically-mediated processes, the adverse consequences would be minimal. The case of Bath is more complex; while the 'waters may be taken' in the Grand Pump Room, the high sulphate content of the water $(\sim 1100 \mathrm{mg} / \mathrm{L})$ renders it not only unpalatable in large quantities, but also gives it a laxative effect. Any leakage into a watersupply borehole could therefore have unfortunate consequences. However, there is already an unknown amount of leakage from the thermal recharge mound beneath central Bath (Stanton 1991); since this is effectively a steady-state situation, any present-day public water abstractions will be sited well away from its influence in order to maintain potability.

The water quality of drainage from most mines is poor owing to the low-pH conditions that result from pyrite oxidation caused by exposure to air during mining operations (e.g. Banks et al. 1997; Wood et al. 1999). In the metal mines of Cornwall, this is compounded by elevated water temperatures and the presence of relatively high concentrations of arsenic-bearing minerals in the rocks through which the waters circulate. Although there is already a major impact on the local environment from legacy mine drainage (e.g. Motsi et al., 2009), adding to this by the discharge of spent thermal brine is clearly not an acceptable option. Either treatment or reinjection would be required: both would be relatively expensive options. One way round this would be to create an engineered geothermal system (EGS), but strictly speaking this does not involve existing thermal groundwater because water is added to a (hopefully) closed-loop system from the surface. In the Carnmenellis Granite a pilot EGS project was carried out at Rosemanowes Quarry in the 1980s. While that project encountered problems both with circulation loss and breakthrough (Barker et al. 2000), a significantly deeper version is currently being constructed in the Redruth area (UDDGP 2019).

Though deep Permo-Triassic basin thermal groundwaters are all basically $\mathrm{Na}-\mathrm{Cl}$ brines (Edmunds, 1986), their TDS loadings vary significantly (Table 3). Nevertheless, even those 
in the lower concentration range would have a deleterious effect on ground and surface waters. While coastal sites may be judged to be an exception (spent brine from the currentlyused Western Esplanade well has so far been disposed of in the tidal Southampton Water), the solution to exploiting these resources further inland must lie in reinjection using the doublet system as found in continental Europe and elsewhere (Mégel and Rybach 2000). The main challenge with these well pairs is minimising the potential for breakthrough between the injection and abstraction boreholes, though this should be rather less of a problem in sedimentary reservoirs compared to typical EGS targets. However, in both cases adequate borehole completions are necessary to ensure that no leakage of poor-quality water can affect overlying freshwaters.

\section{$4 \quad$ Vulnerability of the thermal resource}

While it may be coincidental, the general properties of the three main thermal spring waters considered here (Taffs Well, Buxton and Bath) are all similar: probable circulation time of a few thousand years, and a few percent of modern water entering the system at a late stage (Table 1). Long residence implies large storage, and this combined with the depth of circulation necessary to achieve the inferred maximum temperatures means that such waters are in little danger of disturbance in the far-field. Even extractive operations like shale gas exploitation would be unlikely to affect them as the Carboniferous Limestone lies below the Upper Carboniferous shales which are the most likely target (e.g. Smith and Darling 2012). The presence of minor amounts of modern water is presumably unavoidable in a fracture network conveying thermal water from confined to semi-confined or unconfined conditions, when sufficient hydraulic head exists in the surrounding hills. However, thermal waters can be further disturbed near their outlets by anthropogenic activities, the severity inversely related to distance: for example at Bath, the construction of the (ultimately abortive) Batheaston Coal Shaft in the early $19^{\text {th }}$ Century about $4 \mathrm{~km}$ away led to a slight reduction in hot spring flow, while the deepening of a brewery well in the city centre in 1836 severely reduced flow (Kellaway 1994). Ultimately this led to the introduction of the Bath Act of 1925, applying to development within the city limits, and more recently the much widerranging Section 33 of the County of Avon Act of 1982. This requires permission for boreholes, wells or other excavations descending below a minimum depth of $5 \mathrm{~m}$ bgl in the central zone of the city, $15 \mathrm{~m}$ along the river valley, and $50 \mathrm{~m}$ in the wider area.

Warm inflows in mines indicate that a thermal water resource exists in the Carnmenellis Granite, and conceivably in other cupolas of the SW England batholith. The problem with its exploitation through focused abstraction, presumably by one or more boreholes, lies firstly in knowing where to drill the wells, but secondly in knowing how close operations such as quarrying or mining, or indeed other thermal abstractions, can approach without affecting the original operation. This might occur either by diversion of thermal water, or by causing dilution by cold water. With the as yet poor knowledge of the resource size, a precautionary approach is advisable.

The deep basin waters form a very large thermal resource, with much greater storage than even the warm spring systems. Therefore, significant disturbance in the far-field seems 
highly unlikely, unless (for example) the reservoir became a target formation for CCS (carbon capture and storage) operations. However, such an operation would require major background investigations and could hardly take place accidentally. Much the same would apply to exploitation of oil or gas from sub-Mesozoic formations. Near-field vulnerability should be low; since thermal waters would be exploited by wells 1-2 km deep they would not be subject to any disturbance by near-surface civil engineering works or shallow boreholes.

\section{$5 \quad$ Concluding remarks}

Over the past four decades, geochemistry has helped significantly in understanding the origins of UK thermal groundwaters. Their water quality aspects are well characterised in terms of the threat (if any) to the shallow hydrosphere. In terms of turnover time, however, although much progress has already been made there is still room for improvement. This is perhaps academic as far as the deep basin waters are concerned, since the resource is so large. However, for the warm springs and particularly the granite thermal waters, a better idea of mean residence time is highly desirable. In the case of the springs, a technique yet to be tried is radiocarbon dating using dissolved organic carbon, or DOC (e.g. Wassenaar et al. 1991). This might help to narrow the age range inferred from the combination of stable isotopes and the conventional ${ }^{14} \mathrm{C}$-DIC dating. For the granite waters, should the opportunity arise for further sampling (whether from the reopening of tin mines or from exploration drilling), consideration should be given to new analyses of young age indicators such as the CFCs, the medium-range indicators ${ }^{14} \mathrm{C}$-DIC and -DOC, and a long-term indicator such as ${ }^{81} \mathrm{Kr}$ (e.g. Lehmann et al. 2003).

The thermal groundwaters of the UK are a considerable resource, both potential in terms of total heat stored, and actual in terms of their contribution to tourism (e.g. Bath and Buxton) or to district heating (e.g. Southampton Civic Centre). It is therefore important to know as much as possible about each of the three categories, and geochemical techniques will continue to play a leading role in this process.

Acknowledgements This overview is dedicated to the memory of Paul Younger, geothermal enthusiast, and published with the permission of the Executive Director, British Geological Survey (NERC).

\section{References}

Andrews, J.N., Burgess, W.G., Edmunds, W.M., Kay, R.L.F. \& Lee, D.J. 1982. The thermal springs of Bath. Nature, 298, 339-343.

Arnórsson, S. 2000. Isotopic and chemical techniques in geothermal exploration, development and use. International Atomic Energy Agency. 
Banks, D., Burke, S.P. \& Gray, C.G. 1997. Hydrogeochemistry of coal mine drainage and other ferruginous waters in north Derbyshire and south Yorkshire, UK. Quarterly Journal of Engineering Geology and Hydrogeology, 30, 257-280.

Barker, J.A., Downing, R.A., Gray, D.A., Findlay, J., Kellaway, G.A., Parker, R.H. \& Rollin, K.E. 2000. Hydrogeothermal studies in the United Kingdom. Quarterly Journal of Engineering Geology and Hydrogeology, 33, 41-58.

Birks, D., Younger, P.L., Tavendale, L., Coutts, C., Parkin, G., Button, P. and Whittall, S. 2015. Groundwater reinjection and heat dissipation: lessons from the operation of a large groundwater cooling system in Central London. Quarterly Journal of Engineering Geology and Hydrogeology, 48, 94-103.

Brassington, F.C. 2007. A proposed conceptual model for the genesis of the Derbyshire thermal springs. Quarterly Journal of Engineering Geology and Hydrogeology, 40, 35-46.

Burgess, W.G., Edmunds, W.M., Andrews, J.N., Kay, R.L.F. \& Lee, D.J. 1980. Investigation of the geothermal potential of the UK. The hydrogeology and hydrochemistry of the thermal water in the Bath-Bristol Basin. British Geological Survey Report.

Busby, J. 2014. Geothermal energy in sedimentary basins in the UK. Hydrogeology Journal, 22, 129-141.

Darling, W.G., Edmunds, W.M. and Smedley, P.L., 1997. Isotopic evidence for palaeowaters in the British Isles. Applied Geochemistry, 12, 813-829.

Downing, R.A. \& Gray, D.A. 1986. Geothermal resources of the United Kingdom. Journal of the Geological Society, 143, 499-507.

Downing, R.A., Edmunds, W.M. \& Gale, I.N. 1987. Regional groundwater flow in sedimentary basins in the UK. Geological Society, London, Special Publications, 34, 105125.

Edmunds, W.M. 1986. Geochemistry of geothermal waters in the UK. In: Downing, R.A. \& Gray, D.A. (eds) Geothermal energy: the potential in the United Kingdom. HMSO, London, $111-122$.

Edmunds, W.M., Darling, W.G., Purtschert, R. \& Corcho, J.A. 2014. Noble gas, CFC and other geochemical evidence for the age and origin of the Bath thermal waters, UK. Applied Geochemistry, 40, 155-163.

Edmunds, W.M., Andrews, J.N., Burgess, W.G., Kay, R.L.F. \& Lee, D.J. 1984. The evolution of saline and thermal groundwaters in the Carnmenellis granite. Mineralogical Magazine, 48, 407-424. 
Evans, G.V., Otlet, R.L., Downing, A., Monkhouse, R.A. \& Rae, G. 1979. Some problems in the interpretation of isotope measurements in United Kingdom aquifers. In: Isotope Hydrology 1978, IAEA, Vienna, 679-706.

Farr, G. \& Bottrell, S. 2013. The hydrogeology and hydrochemistry of the thermal waters at Taffs Well, South Wales, UK. Cave and Karst Science Transactions of the British Cave Research Association, 40, 5-12.

Gunn, J., Bottrell, S.H., Lowe, D.J. \& Worthington, S.R. 2006. Deep groundwater flow and geochemical processes in limestone aquifers: evidence from thermal waters in Derbyshire, England, UK. Hydrogeology Journal, 14, 868-881.

Kellaway, G.A. 1994. Environmental factors and the development of Bath Spa, England. Environmental Geology, 24, 99-111.

Lehmann, B.E., Love, A., Purtschert, R., Collon, P., Loosli, H.H., Kutschera, W., Beyerle, U., Aeschbach-Hertig, W., Kipfer, R., Frape, S.K. \& Herczeg, A. 2003. A comparison of groundwater dating with ${ }^{81} \mathrm{Kr},{ }^{36} \mathrm{Cl}$ and ${ }^{4} \mathrm{He}$ in four wells of the Great Artesian Basin, Australia. Earth and Planetary Science Letters, 211, 237-250.

Manning, D.A.C., Younger, P.L., Smith, F.W., Jones, J.M., Dufton, D.J. \& Diskin, S. 2007. A deep geothermal exploration well at Eastgate, Weardale, UK: a novel exploration concept for low-enthalpy resources. Journal of the Geological Society, 164, 371-382.

Mégel, T. \& Rybach, L. 2000. Production capacity and sustainability of geothermal doublets. In: Proceedings World Geothermal Congress, Japan ,Vol. 2, 849-854).

Motsi, T., Rowson, N.A. \& Simmons, M.J.H. 2009. Adsorption of heavy metals from acid mine drainage by natural zeolite. International Journal of Mineral Processing, 92, 42-48.

Richardson, L. 1930. Wells and springs of Gloucestershire. HM Stationery Office, London.

Smith, N. J. P. \& Darling, W.G. 2012. Potential problems within the Bath and North East Somerset Council and surrounding area with respect to hydrocarbon and other exploration and production. British Geological Survey Report.

Squirrel, H. C. \& Downing, R. A. 1969. Geology of the South Wales Coalfield, Part I, the country around Newport (Mon.), 3rd edn. Memoir of the Geological Survey of Great Britain Sheet 249, HMSO, London.

Stanton, W.I. 1991. Hydrogeology of the hot springs of Bath. In: Kellaway, G.A. (ed.) Hot Springs of Bath, Bath City Council, Bath, 127-42.

UDDGP (United Downs Deep Geothermal Power project), 2019. Website https://www.uniteddownsgeothermal.co.uk/ accessed 15 January 2019. 
Wassenaar, L.I., Aravena, R., Hendry, M.J. \& Fritz, P. 1991. Radiocarbon in dissolved organic carbon, a possible groundwater dating method: case studies from western Canada. Water Resources Research, 27, 1975-1986.

Wood, S.C., Younger, P.L. \& Robins, N.S. 1999. Long-term changes in the quality of polluted minewater discharges from abandoned underground coal workings in Scotland. Quarterly Journal of Engineering Geology and Hydrogeology, 32, 69-79.

Younger, P.L., Boyce, A.J. \& Waring, A.J. 2015. Chloride waters of Great Britain revisited: from subsea formation waters to onshore geothermal fluids. Proceedings of the Geologists' Association, 126, 453-465.

Younger, P.L., Manning, D.A., Millward, D., Busby, J.P., Jones, C.R.\& Gluyas, J.G. 2016. Geothermal exploration in the Fell Sandstone Formation (Mississippian) beneath the city centre of Newcastle upon Tyne, UK: the Newcastle Science Central deep geothermal borehole. Quarterly Journal of Engineering Geology and Hydrogeology, 49, 350-363. 
Table 1. Data relating to circulation and residence time of the principal thermal spring waters of the UK. Circ. - circulation, T - temperature. Sourced from Evans et al. (1979), Burgess et al. (1980), Brassington (2007), Farr and Bottrell (2013) and Edmunds et al. (2014).

\begin{tabular}{|l|c|c|c|c|c|c|}
\hline Site & $\begin{array}{c}\text { T outflow } \\
{ }^{\circ} \mathrm{C}\end{array}$ & $\begin{array}{c}\text { Mean age } \\
\text { ka }\end{array}$ & $\begin{array}{c}\text { Young water } \\
\%\end{array}$ & $\begin{array}{c}\text { Max T } \\
{ }^{\circ} \mathrm{C}\end{array}$ & $\begin{array}{c}\text { Circ. depth } \\
\mathrm{m}\end{array}$ & Age tracers \\
\hline Taff's Well & 22 & $\sim 5$ & $<5$ & 27 & 600 & ${ }^{14} \mathrm{C},{ }^{3} \mathrm{H}, \mathrm{CFCs} / \mathrm{SF}_{6}, \delta^{13} \mathrm{C}, \delta^{18} \mathrm{O} / \delta^{2} \mathrm{H}$, noble gases \\
Buxton & 27 & $\sim 5$ & $<5$ & 35 & 1000 & ${ }^{14} \mathrm{C},{ }^{3} \mathrm{H}, \mathrm{CFCs} / \mathrm{SF}_{6}, \delta^{13} \mathrm{C}, \delta^{18} \mathrm{O} / \delta^{2} \mathrm{H}$, noble gases \\
Bath & 45 & $5-10$ & $\leq 5$ & 70 & 3000 & ${ }^{14} \mathrm{C},{ }^{39} \mathrm{Ar},{ }^{3} \mathrm{H}, \mathrm{CFCs} / \mathrm{SF},{ }^{85} \mathrm{Kr}, \delta^{13} \mathrm{C}, \delta^{18} \mathrm{O} / \delta^{2} \mathrm{H}$, noble gases \\
\hline
\end{tabular}

Table 2. Data used to infer the residence time of thermal inflows in tin mines of the Carnmenellis Granite. Sourced from Edmunds et al. (1984).

\begin{tabular}{|l|l|c|c|c|c|c|c|}
\hline Site & Mine Level & $\begin{array}{c}\text { Depth } \\
\mathrm{m} \text { bgl }\end{array}$ & $\begin{array}{c}\mathrm{T} \\
{ }^{\circ} \mathrm{C}\end{array}$ & $\begin{array}{c}{ }^{3} \mathrm{H} \\
\mathrm{TU}\end{array}$ & $\begin{array}{c}{ }^{14} \mathrm{C} \\
\mathrm{pmc}\end{array}$ & $\begin{array}{c}{ }^{4} \mathrm{He} \\
\mathrm{cm}^{3} \mathrm{STP} / \mathrm{g} \times 10^{-8}\end{array}$ & $\begin{array}{c}\mathrm{TDS} \\
\mathrm{mg} / \mathrm{L}\end{array}$ \\
\hline Mt Wellington & Moor Cross-cut & 240 & 21.6 & 30 & 71.6 & 1360 & 890 \\
South Crofty & Robinson's & 700 & 43.0 & 12 & 42.9 & 15500 & 11400 \\
South Crofty & Hot Dry & 700 & 41.5 & 7.4 & 42.4 & 21100 & 19000 \\
\hline
\end{tabular}

Table 3. Comparison of basic hydrogeochemical data from deep boreholes in Permo-Triassic basins of the UK. TDS - total dissolved solids. Sourced from and Edmunds (1986) and Darling et al. (1997).

\begin{tabular}{|l|l|c|l|c|c|c|c|}
\hline Borehole & Basin & $\begin{array}{c}\text { Total depth } \\
\mathrm{m} \text { bgl }\end{array}$ & Formation & $\begin{array}{c}\text { Temp } \\
{ }^{\circ} \mathrm{C}\end{array}$ & $\begin{array}{c}\text { TDS } \\
\mathrm{g} / \mathrm{L}\end{array}$ & $\begin{array}{c}\delta^{18} \mathrm{O} \\
\%\end{array}$ & $\begin{array}{c}\delta^{2} \mathrm{H} \\
\%\end{array}$ \\
\hline Larne No 2 & N Ireland & 2880 & Permian & 40 & 198 & -3.2 & -19 \\
Ballymacilroy & N Ireland & 1981 & Triassic & 62 & 110 & -7.3 & -47 \\
Ballymacilroy & N Ireland & & Permian & 78 & 117 & -7.5 & -46 \\
Cleethorpes & E Yorks \& Lincs & 2100 & Triassic & 53 & 80 & -6.6 & -46 \\
Cleethorpes & E Yorks \& Lincs & & Permian & 64 & 230 & -0.3 & -5 \\
Kempsey & Worcester & 2310 & Triassic & 32 & 6 & -7.9 & -53 \\
Kempsey & Worcester & 230 & Permian & 63 & 22 & -7.4 & -50 \\
Marchwood & Wessex & 2617 & Triassic & 73 & 103 & -3.1 & -29 \\
W Esplanade & Wessex & 1827 & Triassic & 76 & 125 & -2.1 & -26 \\
\hline
\end{tabular}




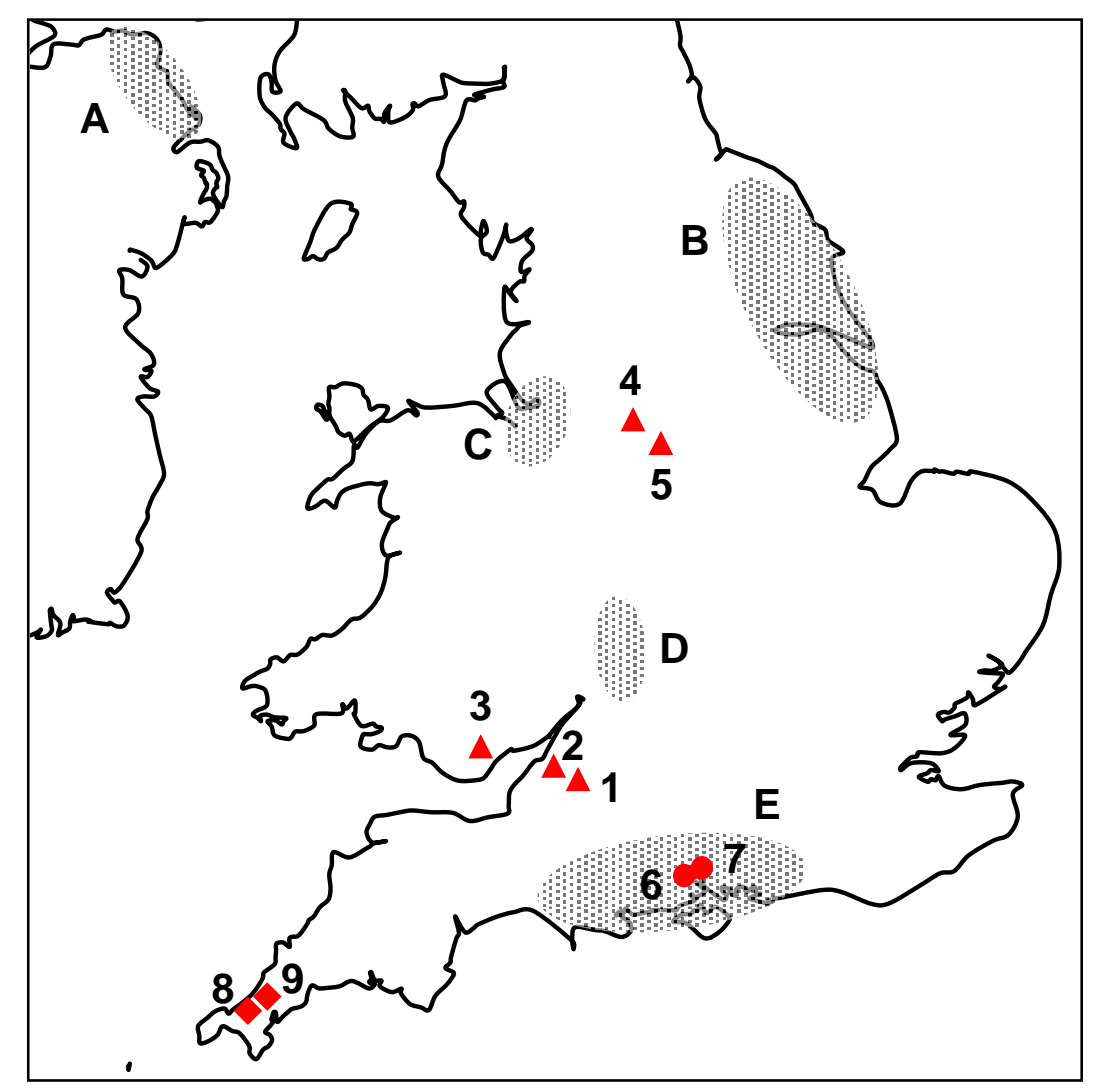

Fig. 1. Location of sites and Mesozoic basins mentioned in the text. Sites: 1 - Bath, 2 - Hotwells, 3 - Taffs Well, 4 - Buxton, 5 - Matlock Bath, 6 - Marchwood, 7 - Western Esplanade, 8 - South Crofty, 9 - Wheal Jane. Permo-Triassic basins: A - Larne, B - East Yorkshire and Lincolnshire, C - Cheshire, D - Worcester, E - Wessex. 
Age in years

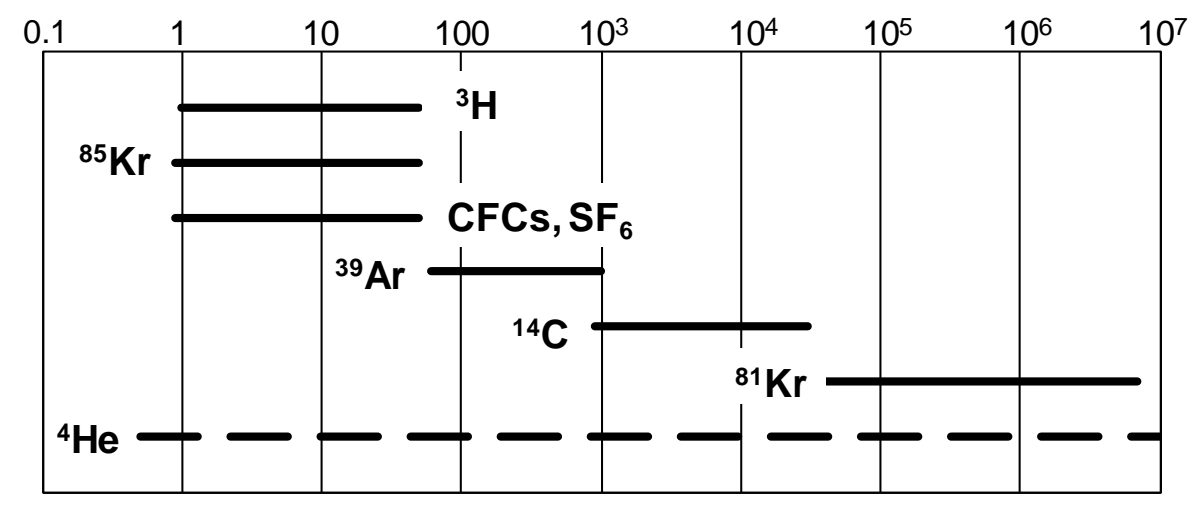

Fig. 2. The age ranges of residence time indicators applied to investigations of thermal groundwaters in the UK (or potentially applicable in the case of ${ }^{81} \mathrm{Kr}$ ). Note that the ${ }^{4} \mathrm{He}$ technique is based on the accumulation of radiogenic He which can vary significantly between aquifers and therefore has no fixed age range. Excluded from the figure are stable isotopes and noble gases, which in an age context are acting as temperature indicators and can only distinguish between Holocene and Ice Age recharge (boundary at approximately $10^{4}$ years). 


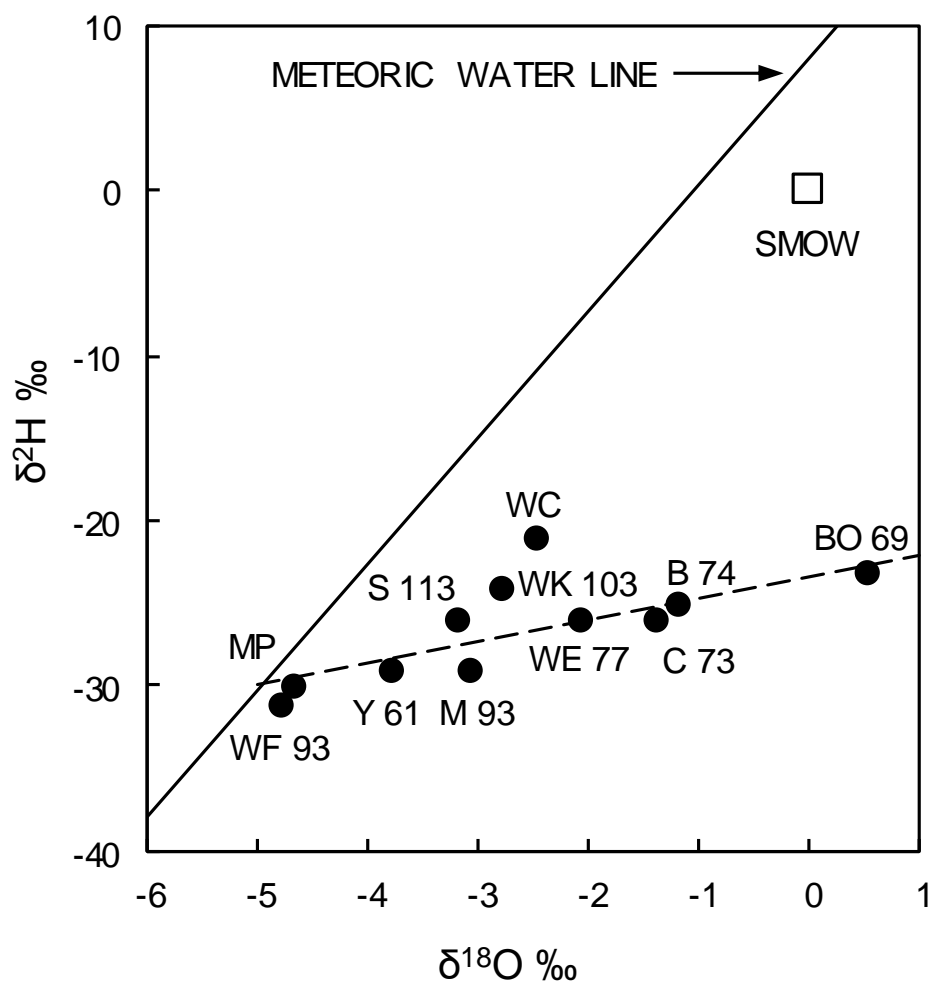

Fig. 3. Stable isotope data from deep wells in the Wessex Basin. BO - Bournemouth Offshore, B - Bushey Farm, C - Chilworth, M - Marchwood, MP - Mappowder, S - Shrewton, WC - Waddock Cross, WE - Western Esplanade, WF - Wytch Farm, WK - Winterborne Kingston, Y - Yarnbury. Numerical values represent highest temperatures $\left({ }^{\circ} \mathrm{C}\right)$ measured in the wells. SMOW- standard mean ocean water. 